\title{
Eye Neoplasm
}

National Cancer Institute

\section{Source}

National Cancer Institute. Eye Neoplasm. NCI Thesaurus. Code C3030.

A benign or malignant neoplasm affecting the structures of the eye. 